\title{
P3078
}

\section{電気メスの火花による消毒用アルコールへの 術中引火事故とその対策}

林 正人 ${ }^{1}$

${ }^{1}$ 協立病院 整形外科

【はじめに】手術室内での引火、炎上事故は、後を絶たないと言われているが 1)、電気メスの火花による 消毒用アルコールへの引火事故の報告は、本邦で過去 3 件 1-3）と極めて少ない。今回、術中皮膚消毒に 用いたエタノールアルコール含有殺菌消毒液（クロルヘキシジン製郕）（以下、消毒液）に電気入スの火花が 引火し、さらに術野のドレープ上に付着していた消毒液が炎上し、患者が火賃を負った症例を経験したので 報告すると共に、本邦での過去の報告例と合わせて、その事故対策を考察した。

【自験例】症例は、左大腿骨頝部骨折の 91 歳男性。腰椎麻酥下に率引ベッド上で、骨折観血的手術を施行 した。消毒用イソジン液で体表皮唐を消毒後、全身に覆布を掛け術野の皮唐のみが露出する状態とした。術 野の皮唐を消毒液で消毒し、乾いたガーゼで余分な消毒液を拭き取った後、ドレープで体表を覆った。ドレ 一プを消毒液で消毒し、メスにて皮覤に切開を加えたが、その際、ドレープ上には消毒液が付着していた。 皮下組織の切開中、電気メスで止血操作を行っていたところ、電気メスの先端から火花が見え、暫くすると、 術者の手に熱感を感じた。この時、術者には、炎は見えなかった。熱感が続くため、術者は握っていた消毒 液浸透ガーゼを排液詝留用バケツ内に括て、再度、手を見たが炎の確認はできなかった。

その時、約 $1 \mathrm{~m}$ 離れた場所にいた看護師が、術野の炎を発見した。排液捕集用具の皮膚から約 $5 \mathrm{~cm}$ 離れて いる部分が炎上していた。直ちに、滅菌水を掛けて消火した。排液貯留用バケツ内のガーゼも炎上していた ため、同様に消火した。

手術終了後、術野の皮居を確認すると、ドレープ・覆布は外見上变化がない場所にもかかわらず、手術創 周囲に約 $8 \mathrm{~cm} \times 10 \mathrm{~cm}$ の発赤と約 $2 \mathrm{~cm} \times 3 \mathrm{~cm}$ の皮唐剥離を認めた。皮酋症状は、火傷時電気入スを操作してい た位置で炎の上がる方向がもっとも酷かったが、ドレープに覆われ部位で消毒液の垂れ下がる方向にも発赤 が広く認められた。

【考察とまとめ] 自験例及び報告例を踏まえて、この引火事故に対し次の対策を考えた。A）余分な消毒淮 は拭取る2)。また、多量の消毒液の使用は控える。B）アルコールの炎は「極めて薄い青色」のため3)、 術者には、炎が視認困難で、手に熱感を感したら火炎発生と考え、周囲の全員に注意を喚起する。少し離れ ている介助者の方が見付け易いこともある。C) 消毒液を多量に使った場合は、覆布を剥して、他の場所で

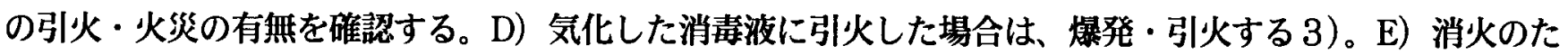
め、洗浄用生理食塩水や滅菌水は、手術の介助者に容易に手渡せる場所に置く。F）ドレープや覆布に肉眼 的な変化がなくても、火傷が存在しその範囲・程度は予想外に広くて重い可能性が高い。火傷の治療を適切 に行う。皮䖒移植が必要となる場合もある 3$)$ 。G)術者は、自身の火俱防止のため、2 重に手術手袋を着用す る。

【文献】 1）林、佐藤、他 : 手術医学 16 巻（p222）1995 2）長野、大毛、他 : 環境感染 17 巻（p 141） 20023 3) 高野、中井川、石井 : 手術医学 24 巻 (p50) 2003 